Marquette University

e-Publications@Marquette

Theology Faculty Research and Publications

Theology, Department of

$1-1-2014$

The Theological Virtues and Participation in Active and Passive Spiration

Robert M. Doran

Marquette University, robert.doran@marquette.edu

Published version. Lonergan Workshop, Vol. 25, No. 1 (2014): 85-93. DOI. (C) 2014 Lonergan Institute at Boston College. Used with permission. 


\title{
THE THEOLOGICAL VIRTUES AND PARTICIPATION IN ACTIVE AND PASSIVE SPIRATION
}

\author{
Robert M. Doran, S.J. \\ Marquette University \\ Milwaukee, Wisconsin
}

I HAVE BEEN ATTEMPTING FOR SOME TIME to work out the meaning of Bernard Lonergan's statement that sanctifying grace may fittingly be understood as a created imitation of and participation in divine active spiration, that is, in the Father and the Son as together they breathe the proceeding Love that is the Holy Spirit, and that charity may fittingly be understood as a created imitation of and participation in divine passive spiration, that is, in the Holy Spirit breathed as the proceeding Love of the Father and the Son. ${ }^{1}$ The particular precision that I wish to bring to this theological hypothesis in the present paper has to do with the place of the theological virtues of faith, hope, and charity in our participation in active and passive spiration, that is, in divine life. That development occurs in section 3 of the paper. What precedes and follows it is a restatement of positions that I have suggested more fully elsewhere, including in previous papers presented at this Workshop.

\section{ACTIVE AND PASSIVE SPIRATION}

The opposed mutual relations of the Father speaking the Word and the Word spoken by the Father (that is, of the notional acts dicere and dici, "to speak" and "to be spoken") together, and precisely in and because of the mutual opposition of generating and generated, are the principle

1 See Bernard Lonergan, The Triune God: Systematics, vol. 12 of the Collected Works of Bernard Lonergan, ed. Robert M. Doran and H. Daniel Monsour and trans. Michael G. Shields (Toronto: University of Toronto Press, 2007), 470-73. 
of another relation that is opposed to both of them considered together, because it proceeds from them precisely as they are paternity and filiation. As such a unified principle - duo Spirantes, unus Spirator they are said actively to breathe Love, and the Love that is breathed is the Holy Spirit. For the Father to beget the Son and for the Son to be begotten of the Father is for the Father and the Son together to breathe the Spirit of love. That is the meaning of the theological doctrine that active spiration, while conceptually distinct from paternity and filiation, is really identical with those two relations together. Two really distinct mutually opposed relations (Speaker and Word, Dicens and Verbum, Father and Son) together constitute one relation (active spiration) only conceptually distinct from Father and Son, a relation that stands as principle to the relation of Love that proceeds from dicere and dici together. That proceeding Love, as relation, is thus appropriately called passive spiration.

\section{PARTICIPATIONS IN ACTIVE AND PASSIVE SPIRATION}

The Holy Spirit is thus God's first gift, so much so that 'Gift' is a personal name for the Holy Spirit, a proper and not appropriated name. ${ }^{2}$ The Holy Spirit is the gift that the Father and the Son eternally give to each other as together, precisely as the Father generating and the Son generated, they communicate the divine nature to the relation of love that unites them.

If the Holy Spirit is God's first gift, a theology of the divine missions would begin, in the order of teaching as contrasted with the order of discovery, with the mission of the Holy Spirit, with the first gift. ${ }^{3}$ All other supernatural divine gifts, including the visible mission of the incarnate Word and the indwelling of the Father and the Son, are somehow 'in' the Holy Spirit as first Gift.

2 See Thomas Aquinas, Summa theologiae, 1, q. 38, aa. 1 and 2. The implications for dialogue with some postmodern concerns with "gift" remain to be worked out.

3 This is the basic thesis in Frederick E. Crowe's programmatic essay, "Son of God, Holy Spirit, and World Religions," on which my work has drawn extensively. The essay appears in Appropriating the Lonergan Idea, ed. Michael Vertin (Toronto: University of Toronto Press, 2006), 324-43. 
If the divine missions are the divine processions linked to created, contingent terms that are consequent conditions of the truth of the affirmation of the missions, ${ }^{4}$ then the mission of the Holy Spirit historicizes and universalizes the eternal Gift uniting the Father and the Son. The issue here is the nature of the created term that is the consequent condition of the truth of any contingent affirmation that the uncreated Gift has been given to us.

If one follows Lonergan in the hypothesis under consideration and I must admit that there is evidence that Lonergan himself in his later work did not regard the hypothesis as being as important as I and others have taken it to be - that consequent condition has two components. The first is consequent upon the Father and Son giving the eternal Gift, and the second is consequent upon the Holy Spirit, the eternal Gift, being given. The first component, then, consequent upon Father and Son giving the eternal Gift, must be some created base of a created relation to the uncreated Gift that has been given. That created base thus imitates and participates in divine active spiration, since it establishes a created relation to the Holy Spirit. The second component, consequent upon the Holy Spirit, the eternal Gift, being given in time, must be the base of a created relation in return, as it were, to the Father and the Son. That created base thus imitates and participates in divine passive spiration, since it establishes a created relation to the Father and the Son.

The first component has been known in the tradition as sanctifying grace and the second as charity. Sanctifying grace is to charity as active spiration is to passive spiration. Created habitual grace has a trinitarian structure.

The offer of this gift of participation in active and passive spiration through created relations to the three divine persons, relations whose created base is, respectively, sanctifying grace and charity, is universal. It is offered to all men and women at every time and place. It is differentiated, however, and made explicit through the divine revelation recorded in the Jewish and Christian scriptures. As Christians profess in the creed, the Holy Spirit 'spoke through the prophets.' And as the letter to the Hebrews affirms, in the visible mission of the incarnate

${ }^{4}$ For the argument to this effect, see The Triune God, 454-67. 
Word God speaks to us through the Son. This visible mission occurs 'in' the Holy Spirit and in relation to the Holy Spirit's universal mission.

Thus, the mission of the Holy Spirit, that is, the gift of divine love, is not only intensified but also revealed, made thematic, in the visible mission of the Son, where it plays a constitutive role. Moreover, a visible mission of the Holy Spirit at Pentecost fulfills the twofold mission of the Son and the Spirit and enables a public acknowledgment that what happened in Jesus was indeed the revelation of the triune God in history. That fulfilment and confirmation are the birth of the church. The Pentecostal mission of the Holy Spirit is precisely the mission of giving birth to the church, whose own mission it is to carry to the ends of the earth and to the end of time the invisible mission of the Spirit and the revelation of that mission in the visible mission of the Son. The mutual interplay of divine and human freedom can now be carried on in explicit recognition of what, prior to the revelation that comes to its fulfilment in the mission of the incarnate Word, necessarily remained vécu but not thématique, implicit but not recognized, conscious but not known, or to employ a Scholastic designation, present in actu exercito but not in actu signato. The visible mission of the incarnate Word is the explicit revelation through linguistic and incarnate meaning, and drawing on the other carriers of meaning as well, of what God has always been doing and continues to do in the inner word of the invisible mission of the Holy Spirit. The church is born in the visible, tangible, audible, palpable mission of the Holy Spirit at Pentecost, precisely to proclaim both divine missions. 'As the Father has sent me, so I send you. And when he had said this, he breathed on them and said to them, "Receive the Holy Spirit."

\section{FAITH, CHARITY, HOPE}

Sanctifying grace is gratia gratum faciens, the grace that makes us pleasing to God in a special way, so that we are elevated to become participants in the divine nature. That participation shares in active and passive spiration, in active spiration through sanctifying grace and in passive spiration through the charity whereby God is loved in return. This gift of mutually reciprocal relations can be made available 
to consciousness in several ways, one of which is through recollection or memory providing evidence sufficient for the silent, indeed ineffable, judgment of value that assents to being on the receiving end of unqualified love. The unqualified love that one receives is what Aquinas calls the 'notionaliter diligere' of Father and Son actively making us lovable in this special way. Participation in divine life is conditioned by the created relation to the Holy Spirit, a relation whose base is the elevating grace known as gratia gratum faciens. There is a graced memoria, a transformed state in which the mind finds itself (Augustine), a transformed Befindlichkeit accompanying Verstehen (Heidegger), a transformed affective movement of life in which the operations of intentional consciousness find direction (Lonergan, Voegelin, Doran). This graced memoria or recollection functions in an analogy based in grace as the analogue for the divine Father, precisely as it provides evidence grasped as sufficient for the judgment of value that assents to the gift of divine love. That assent changes everything in a person's life. The proceeding judgment of value is the faith born of religious love, and it establishes a new horizon for everything. ${ }^{5}$ It functions in the same analogy as the analogue for the divine Word. From memoria and faith breathing love operating (operans) together, there proceeds charity, a disposition of universal willingness that is love of the givers of the gift in return. As Christians grow in the Christian life, that love becomes more and more an explicit relation of companionship with the divine Word made flesh and an explicit relation of hope for the vision of the divine Father. For those who do not have the revelation that makes all this explicit, that love is a love of wisdom and a hope that keeps the quest for truth alive against all odds. The trinitarian structure of active and passive spiration is present in the graced dimensions of all who have received the gift, whether or not it is articulated thematically as trinitarian on the basis of God's revelation in the inçarnate Word.

In this way, it may be maintained, we can affirm the presence of the theological virtues in the lives of all who have assented to the gift, whether that assent be vécu or thématique, implicit or explicit, in actu exercito or in actu signato, merely conscious or also known. Once a supernatural existential is acknowledged to be part

5 See Bernard Lonergan, Method in Theology (Toronto: University of Toronto Press, multiple printings), 117-18. 
of the transcendental interpersonal structure of Dasein, an equally transcendental functioning of the theological virtues of faith, hope, and charity may be discerned, whether that functioning be simply conscious or also known. It is the revelation given in the visible mission of the incarnate Word that makes it known, but it is present and operative independently of that revelation and that knowledge. This does not make the outer word of revelation superfluous, no more, says Lonergan, than the words 'I love you' spoken by two human beings to one another are superfluous to their relation of love. ${ }^{6}$ Those words are constitutive of the relation, as are the explicitations, made possible by the Incarnation of the Word, of the dimensions of the divine gift.

This, I believe, is one way to constitute the basic structure of a Catholic and trinitarian theology of the world's religions. The implications for systematic theology are at least the following.

\section{IMPLICATIONS FOR SYSTEMIC THEOLOGY}

First, the functional specialties now become specialties for a world theology. The eight functional specialties are now to be applied precisely by Catholic theology to the universal religious situation of humankind. The relevant data for research precisely in Christian theology and not just in religious studies include all the data on the religious living of men and women at every time and place. They are to be interpreted by a critical realist hermeneutics. The history relevant to Christian theology includes the religious history of all people. Religious studies would stop there, but theology will go on to the remaining functional specialties, sorting out positions and counterpositions, articulating the horizon for direct discourse, deriving the categories to be employed in that discourse and in ever renewed interpretation of the data and in histories of what was going forward, stating doctrinal positions that will now include what is judged positional from other traditions, working these into systematic coherence, and contributing to the church's mission in the world, precisely and mainly by clarifying the religious situation itself in which that mission is to be fulfilled.

6 See Method in Theology, 112-13. 
Second, the structure specifies only the relations between religious values and personal values in the integral scale of values that in earlier work I tried to establish as providing a central set of categories for a theology of history. ${ }^{7}$ It is above all participation in the invisible mission of the Word that will extend grace to cultural values and to the social mediation of the human good, so that we may speak of social grace. One way in which this will happen is through the reorientation and integration of common sense and of the other sciences on the basis of an explicit articulation of the normative horizon. I want to speak of an invisible mission of the Word, not just by appropriation, but with proper predication. ${ }^{8}$

Third, the four-point hypothesis from which I take the basic set of relations that I have been concerned with here constitutes what I am calling the contemporary dogmatic-theological context for the collaborative construction of a systematic theology. In addition to the participations in active and passive spiration that I take as my starting point, the hypothesis includes specifications regarding the 'secondary act of existence' of the Incarnation and the 'light of glory' opening upon the beatific vision. These I cannot go into here. But in the order of teaching the starting point of any systematics, on a macro level, would treat the Trinity, the gift of the Holy Spirit, the Incarnation, and the promise of beatific knowing and loving in eternal life, and, I propose, would do so in that order. These are the absolutely supernatural realities in which God is attained as God is in God's own triune being. Moreover, they have already received firm and clear doctrinal status in the church's own development of its constitutive meaning. Further development will inch theology and the church toward an equally firm dogmatic-theological framework including positions on revelation, original sin, redemption, creation, the church, the sacraments, and the very large category of praxis, which we have already touched upon in speaking of the reorientation of commonsense living in harmony with an integral scale of values, and also of the interdisciplinary collaboration that would head toward reoriented human science and a new formulation of philosophy's contribution to the articulation of

7 See especially Robert M. Doran, Theology and the Dialectics of History (Toronto: University of Toronto Press,1990, 2001).

8 In contrast, see The Triune God, 498-99. 
foundational reality. In other words, the dogmatic-theological context will expand as systematics does its work.

Fourth, the same hypothesis is one of two parts in what I am calling the unified field structure for systematics. Systematics has to start somewhere, and following Lonergan it has to follow the order of teaching, as opposed to the order of discovery. Aquinas's master edifice was the result not only of his biblical commentaries and Philip the Chancellor's theorem of the supernatural - these gave him the special categories in his theology - but also of his appropriation of Aristotle's metaphysics and, by extension, of Aristotle's psychology, ethics, and even physics. Because he brought these general categories into systematic integration with the transformative realities expressed in the special categories, he transformed Aristotle's philosophy into the systematic Begrifflichkeit that could provide the integration that made his own theology systematic. His unified field structure, if you will, was a function of the combined power of the theorem of the supernatural and his appropriation of Aristotle. I am suggesting that it is continuous with Aquinas that a contemporary unified field structure for systematics be composed of the four-point hypothesis, which differentiates the theorem of the supernatural, and what Lonergan calls the Grund-und Gesamtwissenschaft, the total and basic science, which represents the culmination to date of the effective history of Thomas's Aristotelianism: namely, Lonergan's cognitional theory, epistemology, metaphysics, and existential ethics. I have also suggested that this general-categorial component to the unified field structure be further specified by bringing Lonergan's basic and total science to bear on the construction of a theory of history, so that systematics may take as its mediated object precisely what Lonergan at the time of his breakthrough to functional specialization said it should take as its mediated object, namely, Geschichte, the history that is lived and written about. So the four-point hypothesis and a theory of history based in Lonergan's fundamental achievement would constitute the unified field structure for a contemporary systematic theology.

This unified field structure is not fixed for all time any more than Aquinas's corresponding structure was fixed for all time. Both components in the structure will develop. The special-categorial domain in the realm of the supernatural will unfold as secure 
achievements in understanding revelation, sin, redemption, creation, the church, and so on, go forward. And the general-categorial domain in the realm of history will unfold as the human sciences, including economics, are reoriented and incorporated into that part of the unified field structure that constitutes a theory of history. The scale of values frames that theory of history, and the four-point hypothesis, especially as it names the immanent constitution of life in God, constitutes the realm of 'religious values' in that understanding of history. Fidelity to the work of participating in the invisible mission of the divine Word will enable the systematics of history to develop its understanding of the other levels of value: personal, cultural, social, and vital, in an ongoing mediation between an increasingly global cultural matrix and the significance and role of religious living in that matrix.

But the expansion of the specification of religious values themselves will also go forward as a Catholic trinitarian systematic theology finds its home in the midst of the explicit application of the functional specialties to a world theology, a theology that would discern, locate, and appropriate the gifts of the universally bestowed Holy Spirit in the religious living of all people. Such, I think, was what Lonergan was anticipating in his 'Prolegomena to the Study of the Emerging Religious Consciousness of Our Time, ${ }^{, 9}$ where he may legitimately be interpreted as implying not only that a contemporary systematics must be grounded in interiorly and religiously differentiated consciousness, and not only that it must take the form of a theology of history, but also that it must be expressed in the explicit context of the interreligious and multi-religious world in which we live.

9 Bernard Lonergan, "Prolegomena to the Study of the Emerging Religious Consciousness of Our Time," in A Third Collection, ed. Frederick E. Crowe (Mahwah, NJ: Paulist Press, 1985), 55-73. 